\title{
Envoys and Traders to Northern Song China
}

Qarakhanid and other Islamic sources provide scant information on relations with China. In these sources, China is referred to as al-Ṣinn/Chīn, Māṣinn/ Māchīn, Tawghāj/Tabghāch, and Khitāy/Qitāy, terms that could be used in a general or specific sense, and it is not always easy to determine to which particular region or dynasty they were applied. ${ }^{1}$

In contrast, Chinese sources contain detailed information on the Qarakhanid envoys sent to Chinese emperors, especially to the Northern Song court, including exact dates, names, diplomatic gifts and loans, trade roads, and passages, as well as letters and documents exchanged between the Song emperors and Qarakhanid Khagans. Chinese texts confirm that Qarakhanid messengers served as diplomats and traders as well as provided military service in Song China. This kind of information is not available in Qarakhanid or other Central Asian sources. However, Qarakhanid history has long been considered a research subject for Turkologists, and Chinese sources were usually not consulted. Major scholarly works on Song China also seldom deal with SongQarakhanid relations. ${ }^{2}$ Therefore, many aspects of Qarakhanid activities in the East have remained largely unknown.

This chapter utilizes Song records on the Qarakhanids and introduces unknown sides of the Qarakhanid commercial diplomacy in China, including discussion on the presence of women in official Qarakhanid delegations and female mobility in the eleventh-century Turkic society. It also presents Qarakhanid envoys as cartographers at the Song court and discusses Song dynasty maps that depicted Qarakhanid territories.

1 Dīwān lughāt al-Turk, trans. Auezova, 166, 424; Qutadghu bilig, trans. Dankoff, 58; for the Turkic text, see Qutadghu bilig, ed. and trans. Arat, vol. 1, 445; Tabā̄i al-hayawān, ed. and trans. Minorsky, 14-15. Some materials used in this chapter were initially published in: Dilnoza Duturaeva, "Qarakhanid Envoys to Song China," Journal of Asian History 52, no. 2 (2018): 179-208.

2 For an example, see Rossabi, China among Equals. 
The Qarakhanid polity was first known in Song China as Shule guo (the Kashghar state). ${ }^{3}$ After the Qarakhanid conquest of Khotan, it began to be associated with the region of Khotan, mainly due to the frequency with which envoys were dispatched from this place by the Qarakhanids, and named Yutian guo (the Khotan state). In some cases, the Qarakhanids were referred to as Dashi (Muslims). For instance, in the description of Fulin that may refer to the Saljuqs of Rum, Dashi was recorded as one of the eastern neighbors of the Saljuqs located on the way to China before Khotan. ${ }^{4}$ This Muslim state is most likely that of the Western Qarakhanids.

The Qarakhanid realm was generally seen as waiguo (outside country), and people were recorded as fan (barbarians, foreigners) by Song historians. ${ }^{5}$ The word fan has been in use in China since ancient times. During the Tang-Song period, the usage of fan was commonly placed in a pair with the category Han (Chinese) as a geopolitical term used for the foreigners of the west, southwest, and south. ${ }^{6}$ The official historians who compiled the history of the Song dynasty during the Mongol era used the term fan for people of the south and southwest but replaced it with the politically neutral word ren (man, people) for the Qarakhanids. For instance, historians of Song shi used the text about the first envoy from the Qarakhanids that was recorded in Xu zizhi tongjian changbian in a context where the Qarakhanids were depicted as yuan fan (barbarians from the distant place). This term was replaced with yuan ren (people from a distant place) in Song shi. ${ }^{7}$ The Mongol rulers of the dynasty, who shared the same nomadic traditions with Turkic peoples, banned the usage of fan for the Qarakhanids in official historical writings, probably due to its pejorative meaning. However, this term might have been neutral during the Song period. For instance, it was used by the Khitans and the Tanguts as a selfappellation. ${ }^{8}$ Later the Jurchens prohibited the usage of this term for themselves, probably because they did not want to be seen as "outsiders." 9 Perhaps

3 Song shi, 490: 14106-14107.

4 Xu zizhi tongjian changbian, 317: 7661; Song shi, 485: 13981.

5 Qingbo zazhi, 6: 53; Xu zizhi tongjian changbian, 71: 1598.

6 For the usage of fan in different periods, see Endymion Wilkinson, Chinese History: A New Manual (Cambridge, MA: Harvard University Asia Center, for the Harvard-Yenching Institute, 2015), 354; Yang, "Fan and Han," 9-35.

7 Xu zizhi tongjian changbian, 71: 1598; Song shi, 490: 14107.

8 Yang, "Fan and Han," 3 .

9 Ibid. 
due to the Jurchen prohibition, this term was viewed as derogatory during the Mongol period.

The Qarakhanid ruler was referred to by his main title, Qarakhan, translated into Chinese as heihan, ${ }^{10}$ meaning "Black Khan." Chinese official historians of the Mongol era under the leadership of Toqto'a, who compiled Song shi, explained that heihan was a corrupted version of the title kehan, ${ }^{11}$ which is a Chinese transliteration of the Turkic title Khagan. However, this seems to be written from the perspective of the Chinese. The title Qarakhan was translated from the original language by someone familiar with it. Song shi mentioned the title of the Qarakhanid ruler as heihan in the heading of the Qarakhanid letter that arrived at the Song court in 1081 in what is present-day Kaifeng. ${ }^{12}$ The letter was most likely originally written in Turkic and then translated into Chinese. The translator used the words hei (black) and han (khan) to translate the title Qarakhan. This title was also mentioned in earlier letters sent to Chinese emperors by Qarakhanid rulers and wrongly understood as a corruption of the title kehan (Khagan). ${ }^{13}$ Moreover, the title kehan never applied to the Qarakhanid rulers in Chinese sources.

Another title of the Qarakhanids, Tughril Qarakhan, appears in Song shi as houlin heihan. Tughril Qarakhan Yusuf ibn Sulayman (r. 1062-1080) sent an envoy to China in 1063 and requested the titles tejin and guizhong baoshun houlin heihan wang (Specially Advanced and Faithful Commandant for Maintaining Submission Tughril Qarakhan king). ${ }^{14}$ Tejin and guizhong baoshun $^{15}$ are Chinese honorific titles, but houlin heihan are Chinese words for the Turkic title Tughril Qarakhan. The word houlin was explained as a name of the golden-winged bird Garuda in the Qarakhanid language. ${ }^{16}$ Garuda is a mythical bird that appears both in Hindu and Buddhist mythology. The Qarakhanid envoy probably described a tughril, a large falcon in Turkic culture, and the Chinese identified it with Garuda.

\footnotetext{
10 Song shi, 17: 329; 18: 346; 490: 14087, 14107-14109.

11 Song shi, 490: 14108.

12 Song shi, 490: 14109.

13 For the terms heihan and Dashi applied to the Qarakhanids in Chinese sources, also see Michal Biran, "Qarakhanid Studies: A View from the Qara Khitai Edge," Cahiers d'Asia Centrale 9 (2001): 79-80.

14 Song shi, 490: 14108.

15 According to Song shi, 490: 14117, the similar title guizhong baoshun kehan 1023 was also granted to the ruler of the Uyghur Khagan of Ganzhou, Yelage (r. 1023-1028). For the English translation of the title, see Hans Bielenstein, Diplomacy and Trade in the Chinese World, 589-1276 (Leiden: Brill, 2005), 454.

16 Song shi, 490: 14108.
} 
At least one representative of the Qarakhanids was mentioned by name. Song shi recorded Qarakhan Ahududongemijiedu (LMC. Pa-xut-tuǎ-təwýya-mit-khiat-təwk), which may stand for Alp Qutlugh Tonga Majid. ${ }^{17}$ Moreover, Qarakhanid ambassadors also held the title da shouling meaning "main chieftain."18 The Chinese generic term shouling, which literally means "head and neck," usually referred to chiefs of tribal clans, tribes, or even tribal unions and Khaganates. ${ }^{19}$ Therefore, "great head and neck" (da shouling) most likely refers, if not to the ruler himself, at least to one of the high standing members of the dynasty.

\section{The Image of the West in China}

What did the Chinese know about the West during the rule of the Qarakhanids in Central Asia? The western network of the Northern Song dynasty functioned along the continental routes. Their active participants formed the Chinese body of knowledge about the West in the pre-Mongol period, which can be observed in the description of the West recorded by Pang Yuanying. He served at the Northern Song court as zhuke langzhong (Director of the Bureau of Receptions) and was in charge of managing the reception of foreign delegations during the Shenzong rule and Wang Anshi's New Policies.

He recorded nine places in the West in the following order: the Tangut Empire, the Tsongkha kingdom, the Qarakhanid Khaganate, the Uyghurs, Kucha, India, Dunhuang, Qomul, and Turfan:

17 Kochnev mentions that two Qarakhanid rulers used the title "Alp Qutlugh Tonga" on coins. Kochnev, Numizmaticheskaia istoriia, 33. However, all these titles were common among the ruling elite. Ibid, 28-31. Qian Boquan suggested that the name of the Qarakhanid ruler should be read as "Abdu Tonga Majid." Qian Boquan 钱伯泉, “Yichang Kalahan wangchao he Song chao lian bing jingong Xi Xia de zhanzheng: Cangjingdong fengbi de zhenzheng yuanyin 一场喀喇汗王朝和宋朝联兵进攻西夏的战争 - 藏经洞封闭 的真正原因和确切时间 [An Allied Force of the Qarakhanids and the Song Dynasty against the Western Xia: A Real Reason of Sealing of the Library Cave]," Dunhuang yanjiu 敦煌研究 2 (2000): 8. However, according to the system of Islamic names, 'Abdu (servant) can be a part of personal names (ism) only followed by description of God, like 'Abdullāh, 'Abdu al-Raḥmān etc. Tonga (tiger) was a Turkic title commonly used by the Qarakhanids. Therefore, 'Abdu could not be used in conjunction with Tonga.

18 Song shi, 16: 301; 490: 14109; Song huiyao jigao, Fanyi 7: 32.

19 For the usage of the Chinese title shouling in Turkic hierarchy, see Skaff, Sui-Tang China and its Turko-Mongol Neighbors, 35 . 
西方有九: 其一曰夏國, 世有銀、夏、綏、宥、靜五州之地, 慶歷 中, 冊命為夏國。其二曰董亶, 居青唐城, 與回鶻、夏國、于闐相 接。其三曰于闐, 西帶葱嶺, 與婆羅門接。其四曰回鶻, 本匈奴別 裔, 唐號回紇, 居甘、沙、西州。其五曰龜茲, 住居延城, 回鶻之別 種, 其國主自稱師子王。其六曰天竺, 舊名身毒, 亦曰摩伽陀, 又曰 婆羅門。其七曰瓜沙門, 漢燉煌故地。其八曰伊州, 漢伊吾郡也。其 九曰西州, 本高昌國, 漢車師前王之地。有高昌城, 取其地勢高、人 昌盛以為名。正觀中, 按宋人避諱改貞為正。平其地為西州。20

There are nine states in the west: the first one is called the Xia state [Tanguts], their ancestors were in the lands of five prefectures Yinzhou, Xiazhou, Suizhou, Youzhou and Jinzhou, during the Qingli era [10411048] by the Emperor's order it was called the Xia state. The second one is called Dongzhan [Tsongkha]; it is located in Qingtang city and connected with Huigu [Uyghurs], the Xia state [Tanguts] and Yutian [Qarakhanids]. The third one is called Yutian; in the west it is surrounded by Congling [Pamir] and connected with Poluomen [India]. The fourth one is called Huigu [Uyghurs]; they are originally other descendants of the Xiongnu and were called as Huihe during the Tang period, they are located in Ganzhou [Zhangye], Shazhou [Dunhuang] and Xizhou [Turfan]. The fifth one is called Qiuci [Kucha]; they reside in the Juyan city and are another kind of Huigu, the head of their state calls himself the Lion king [Arslan Khan]. The sixth one is Tianzhu [India]; its old name is Juandu, ${ }^{21}$ it was also called Mojiatuo [Magadha] and Poluomen [Brahman]. The seventh one is Guashamen [Guazhou and Shazhou Gate]; it is the previous land of Dunhuang of the Han. The eighth one is Yizhou [Qomul]; it was the Yiwu prefecture of the Han. The ninth one is Xizhou; it is originally the Gaochang state and it was the land of the former Jushi king during the Han period. There was the city Gaochang, and as the position of the land was gao [high] and their people were in chang sheng [flourishing abundance] it was called by this name. In the title of the Zhengguan era, according to the taboo on using personal names of emperors among the Song people, the character zhen was changed to zheng. When this land was pacified it became Xizhou.

This passage on the western territories gives a general view of how the Chinese perceived Central Asia in the eleventh century. Pang Yuanying stated that the

$20 \quad$ Wenchang zalu, 1: 2 .

21 It is also pronounced "Yuandu." 
ruler of the Tsongkha kingdom Dongzhan was bordered by the Tanguts, the Uyghurs, and the Qarakhanids. Moreover, he pointed out that the Qarakhanids of Khotan shared a border in the west with India. This information refers to the Southern Silk Roads that also connected to Tibetan Plateau routes linking Central Asia and South Asia. Pang Yuanying records prove the movement along this network during the Qarakhanids.

According to Chinese records, the Qarakhanids dispatched more than forty missions to the Northern Song from 1009 to $1124 .{ }^{22}$ The exact number of missions is not clear, because envoys could stay in the Xihe Circuit (Xihelu) ${ }^{23}$ for extended periods and visit the court several times per year. Later Emperor Zhezong (1086-1100) issued an edict to limit their visits up to once time per year. ${ }^{24}$

Qarakhanid messengers were mentioned as bancilbanca in the Song official records. ${ }^{25}$ During the Northern Song this term applied to foreign envoys from the west, who also had economic functions including to their diplomatic responsibilities. They were expected to trade as well as protect borders in the Xihe Circuit. For their service banci received generous rewards. ${ }^{26}$ This explains why the Qarakhanids frequently sent military commanders as envoys and received lavish payment at the court. ${ }^{27}$

The term banci started to be used from the tenth century and frequently appeared in Dunhuang documents. ${ }^{28} \mathrm{It}$ is accepted that banci corresponded to

\footnotetext{
22 See Appendix 3.

23 The Xihe Circuit was a subdivision of Shaanxi and was designated in 1072 when Song armies conquered the Tangut prefecture of Hezhou. Following its final pacification in 1074, the Song created official markets at the Xihe Circuit to trade Sichuan tea for horses.

24 Song huiyao jigao, Fanyi 4: 17; also see document 9 in Appendix 2.

25 Xu zizhi tongjian changbian, 475: 11321; Song huiyao jigao, Fanyi 4: 16; 7: 36; 7: 42.

26 Xu zizhi tongjian changbian, 412: 10026; Song huiyao jigao, Fanyi 6: 22. For the functions of banci/banca during the Song dynasty, also see Wang Zhen 王震, "Banca Banci kaozheng “般擦”般次”考证 [Textual Research on Banca and Banci],” Guangxi keji lishi shifan xueyuan xuebao 广西科技师范学院学报 31 , no. 4 (2016): 46-48.

27 See Appendix 3.

28 Zhang Guangda 張廣達, “Tangmo Wudai Songchu xibei diqi de banci he shici 唐末五 代宋初西北地區的般次和使次 [Banci and shici in Northwest China during the Late Tang, Five Dynasties and Early Song]," in Xiyu shidi congkao chubian西域史地叢稿初 編 [Primary Collection of Studies in History and Geography of the Western Regions] (Shanghai: Shanghai guji chubanshe, 1995), 335-346.
} 
the Turkic word arkış, which means "caravan."29 The word arkış was also used to refer to envoys sent to distant places. ${ }^{30}$ Therefore, banci also applied to foreign envoys that arrived from the west along the land roads. The banci system of the Northern Song has similarities with the ortoq institution that functioned during the Mongols. The ortoqs were merchant associations in Yuan China that served as business partners of the Mongol ruling elite. These associations composed mainly of Uyghurs and Muslims who received silver loans from the government and financed trade caravans traveling to Central Asia and Iran. In this sence, the banci system can be a possible institutional precedent for the ortoq.

The Qarakhanids paid great attention to training well-qualified envoys, who were expected to be proficient not only in foreign languages but also in science, poetry, archery, chess, and many other fields. ${ }^{31}$ Remarkably, the Qarakhanids appointed Uyghurs as ambassadors, especially in the initial stage of the relations with Song China, probably due to their language skills. For instance, the first mission from the Qarakhanids sent by Yusuf Qadir Khan in 1009 was led by Huigu Luo Siwen (Uyghur Boyla Saghun). ${ }^{32}$ However, the Chinese sometimes applied the term "Uyghur" to the Qarakhanids in general. Therefore, the envoy could also be from the Qarakhanid realm. Names of Qarakhanid envoys frequently have two characters in the end, such as siwen (LMC. sz-Pun), sawen (LMC. sat-?un), sangwen (LMC. say'-Pun). ${ }^{33}$ For instance, the envoy, who came to the Chinese court in 1063 was called Luo Sawen (Boyla Saghun), ${ }^{34}$ another envoy who arrived in 1077 was Luo Asinan Siwen (Boyla Arslan Saghun). ${ }^{35}$ Siwen/sawen/sangwen was most likely the Chinese transliteration of the Turkic title Saghun, which was given to chieftains of the Qarluqs, according to the Qarakhanid scholar Maḥmūd al-Kāshgharī. ${ }^{36}$ Luo is probably a short version of the Turkic title Boyla that appeared in Chinese sources as peiluo (LMC. phuaj-la). ${ }^{37}$ There were also high military officials (buling) and main chieftains among the Qarakhanid envoys (da shouling). ${ }^{38}$ In some cases, Qarakhanid

29 Takao Moriyasu, "Epistolary Formulae of the Old Uyghur Letters from the Eastern Silk Road (Part 2)," Osaka University Knowledge Archive 52 (2012), 44.

30 For the meaning of the word arkış, see Dīwān lughät al-Turk, trans. Auezova, 128.

31 Qutadghu bilig, trans. Dankoff 125-127; for the Turkic text, see Qutadghu bilig, ed. and trans. Arat, vol. 1, 273-280.

32 Song shi, 490: 4107.

33 Xu zizhi tongjian changbian, 302: 7350, 285: 6972; Song shi, 16: 301, 490: 14107-14108.

34 Song shi, 490: 14108.

35 Xu zizhi tongjian changbian, 285: 6972.

36 Dīwān lughāt al-Turk, trans. Auezova, 379. Also see Osman 2002, 48-52.

37 Osman 2002, 48-52.

38 Song shi, 16: 301, 490: 14109. 
princes were also sent as ambassadors to the Northern Song. ${ }^{39}$ These titles and positions demonstrate that the Qarakhanids appointed high-ranking officials and representatives of the dynasty to be sent to the Song court.

The exact number of delegates is not always clear. According to the imperial edict on the Qarakhanid envoys issued in 1078, each delegation should consist of no more than fifty persons. ${ }^{40}$ Chinese chronicles usually recorded only main envoys. However, in some cases, the names and titles of other delegates were also included. The delegation sent in 1025 consisted of the envoy (shi), the deputy envoy (fushi), the Commissioner (jianshi), and the Military Commandant (dujian). The envoys were lodged in the capital's western postal relay station (duting xiyi) in present-day Kaifeng. ${ }^{41}$

Both missions in 1009 and 1025 were dispatched by Yusuf Qadir Khan, who controlled the Kashghar and Khotan territories and sought to become a head of the Qarakhanids. ${ }^{42}$ As mentioned above, his ambitions caused conflicts with his brother, the main Qarakhanid Khagan 'Ali Tegin, who resided in Samarqand. ${ }^{43}$ For this reason, Yusuf Qadir Khan allied with Sultan Mahmud of Ghazna in $1025^{44}$ and sent two missions to Liao China in 1020 and $1021,{ }^{45}$ as well as two delegations to Song China in 1009 and 1025 . He sought to strengthen his political position on both the western and eastern frontiers.

From 1025 to 1071, only one mission was dispatched by the Qarakhanids from Khotan. It came to the court twice, once on September 21, 1063 and again on February 1, 1064. ${ }^{46}$ This interruption can be explained by the rise of the Tanguts and their military activity in the Hexi Corridor that blocked trade roads to China. Qarakhanid relations with the Tanguts and the Khitans were not always peaceful. Therefore, the Qarakhanids sought to find alternative roads and managed to keep their stations in the Tsongkha kingdom. ${ }^{47}$

After 1071, the envoys came annually, sometimes several times per year. Due to this frequency, in 1087 Emperor Zhezong ordered that they visit court only once a year, and later this was further limited to every other year, which

39 Song shi, 18: 346; 490: 14109 .

$40 \quad$ Xu zizhi tongjian changbian, 295: 719o; Song huiyao jigao, Fanyi 4: 16.

41 Song shi, 490: 14108.

42 Davidovich, "The Karakhanids," 130, 132.

43 Bosworth, "Alītigin," 887-88; Kochnev, Numizmaticheskaia istoriia, 135.

44 Davidovich, "The Karakhanids," 133.

45 Liao shi, 16: 189.

46 Song shi, 490: 14108; Song huiyao jigao, Fanyi 3: 30-31. Also see Appendix 3.

47 On the Tsongkha kingdom and its relations with neighbouring states, see Horlemann, Aufstieg und Niedergang, 83-106. 
prompted complaints by foreign envoys. ${ }^{48}$ As the Prefect of Qinzhou, You Shixiong (1037-1097), reported:

于闐、大食、拂菻等國貢奉, 般次踵至, 有司憚於供賚, 抑留邊方, 限二歲一進。外夷慕義, 萬里而至, 此非所以來遠人也。49

Yutian [Khotan], ${ }^{50}$ Dashi [Muslims], ${ }^{51}$ Fulin $\left[\right.$ Rome ${ }^{52}$ and other states offer tribute to the court, their banci arrive upon the heels of one another, and officials dread terrify about having to provide rewards, so they stop them and keep them on the border and limit them to come to the court once every two years. Foreigners admire our righteousness and arrive through ten thousand $l i$, this is not the way of treating people from afar.

The number of Qarakhanid missions was significantly reduced after 1098. This can be also explained by the Song-Tsongkha military confrontation during this period. The last Qarakhanid envoy from Khotan that was depicted in Chinese official histories arrived at the Song court in $1124 .{ }^{53}$

The Song emperors apparently never sent messengers to the Qarakhanid realm. Yusuf Qadir Khan even asked Emperor Zhenzong to dispatch an official mission, but his request went unheeded. Song shi only recorded a legendary story about a Song soldier who traveled to Khotan in 1017 to find jade for the emperor. ${ }^{54}$ This story illustrates the high demand for Khotan jade in Song China, even during the Qarakhanid era; ${ }^{55}$ however, it can hardly be used as evidence to prove the presence of Song envoys in the Qarakhanid Khaganate.

48 Song shi, 49o: 14109; Song huiyao jigao, Fanyi 4: 17.

49 Xu zizhi tongjian changbian, 300: 7310; Song shi, 490: 14109.

50 This refers to the Eastern Qarakhanids.

51 Delegations from the Muslim state that arrived in China by land roads were mainly dispatched by the Western Qarakhanids and after the Malik Shah's conquest of the Qarakhanid territories in 1089, also by the Great Saljuqs. Arab and Persian envoys and merchants mainly used sea routes.

$5^{2}$ The term Fulin that referred to Byzantium during the Tang period was used for the Saljuq Sultanate of Rum in Song sources. See Chapter 5 .

53 Song shi, 22: 415 .

54 Song shi, 490: 14107-14108.

55 For the Jade trade in the tenth-eleventh centuries, see Rong Xinjiang 荣新江 and Zhu Lishuang 朱丽双, “Cong jingong dao siyi: 10-11 shiji Yutian yu de dongjian Dunhuang yu Zhongyuan 从进贡到私易: 10-11世纪于阗玉的东渐敦煌与中原 [From Tribute to Trade: Eastward Dissemination of the Jades of Khotan into Dunhuang and the Central Plains in the 1oth and 11th Centuries]," Dunhuang yanjiu 敦煌研究 3 (2014): 190-200. 
On the occasion of the New Year, according to the Chinese protocol, foreign envoys were invited to an official ceremony in the palace and an audience with the emperor to offer him diplomatic gifts. One of these New Year ceremonies was described by Meng Yuanlao (c.109o-1150), a Northern Song official who escaped from Kaifeng during the Jurchen invasion and left a detailed description of the Kaifeng's urban life, customs, and traditions of its residents, as well as official ceremonies held at the Northern Song court. In his description of the New Year ceremony, he provided detailed information about foreign delegations that arrived at the court including their appearance and clothing. He described envoys from Liao (Khitans), Xi Xia (Tanguts), Gaoli (Korea), nanfan Jiaozhou (southern barbarians of Jiaozhou), Huihe (Uyghurs), Yutian (Khotan, i.e. Qarakhanids), Sanfoqi (Srivijaya), nanman wu xing fan (five families of southern barbarians), Dali (Yunnan) and Dashi (Muslims). In the description of the Qarakhanid delegation he mentioned that the envoys were accompanied by their women:

于闐皆小金花壇笠、金絲戰袍、束帶, 并妻、男同來, 乘駱駞、氈 兒、銅鐸入貢。56

All the men from Yutian [Khotan] wore small, golden, patterned, conical felt hats, golden silk thread combat robes tied with belts, and arrived together with their wives and sons, and they were riding camels with felt bags and bronze bells, and they offered tribute.

This account shows that Qarakhanid envoys traveled together with their families. Women certainly did travel for business, for family reasons, or to visit holy places. Therefore, their presence in caravans and hostels were not infrequent. In some cases, royal Turkic women could travel independently to perform the hajj. ${ }^{57}$ However, the presence of women in official delegations and particularly their participation in diplomatic ceremonies at the Chinese court are rarely mentioned. The Qarakhanids were the only delegation to arrive at the court with their spouses (or at least, the Chinese official provided this information only in the description of the Qarakhanid envoys). It seems that the situation

$56 \quad$ Dongjing meng Hua lu, 6: 167; Song huiyao jigao, Fanyi 7: 57.

57 Carole Hillenbrand, "Women in the Saljuq Period," in Women in Iran from the Rise of Islam to 180o, ed. Guity Nashat, and Lois Beck (Urbana and Chicago: University of Illinois Press, 2003), 110-111. 


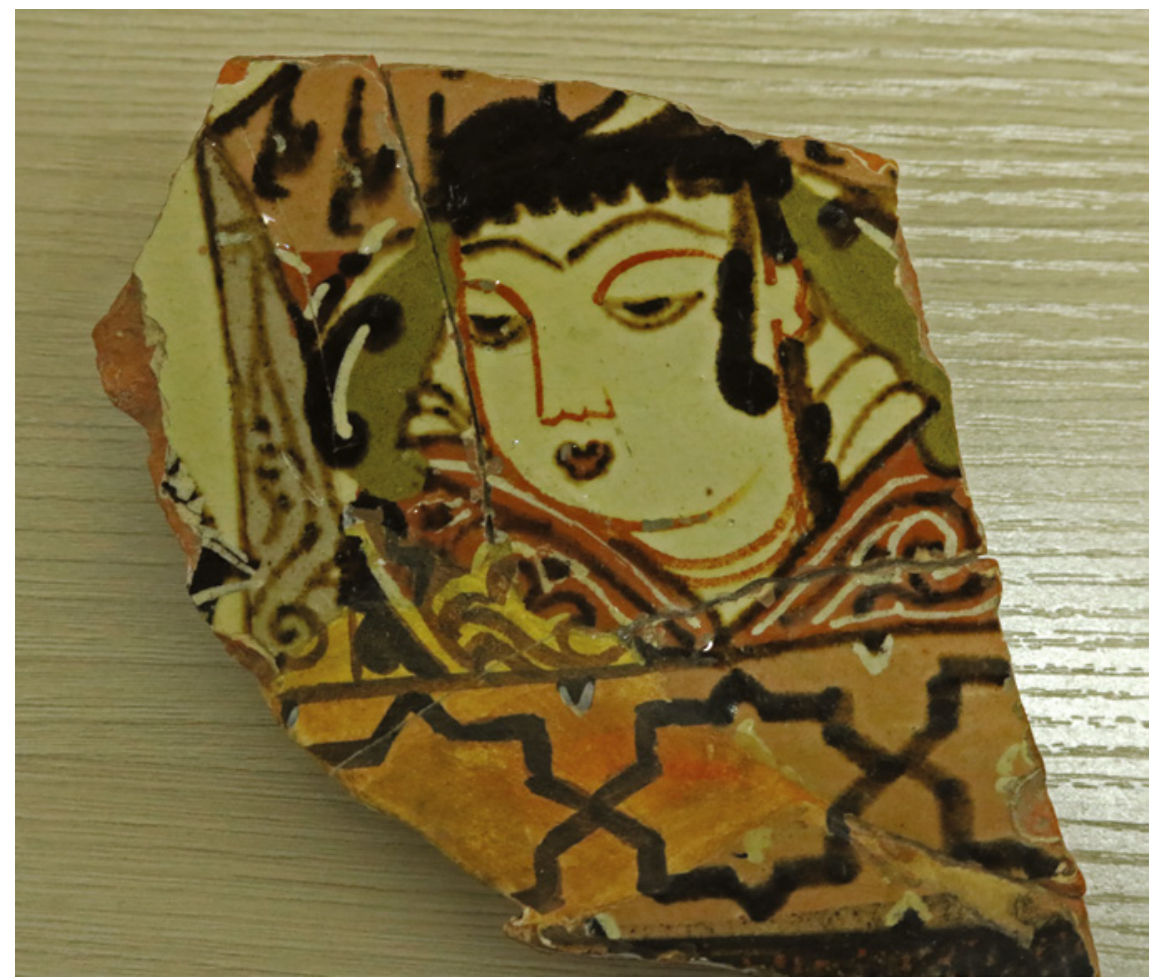

FIGURE 1 Qarakhanid Female Image on a Ceramic Fragment COURTESY OF JAMBYL REGION HISTORY MUSEUM, KAZAKHSTAN

itself was unusual to the author, so he decided to point it out. But perhaps these women were not just conjoints of the envoys. Could they have traveled on business of their own? Regrettably, these women did not leave records of their own travel, so the true reason(s) for their journey will remain unknown. At the same time, the fact that Qarakhanid women traveled to China and managed to attend the audience with the Chinese emperor provides a wide arena for speculation about female mobility and their role in Qarakhanid society.

Qarakhanid society was male-centered. Men were dominant, but women in nomadic and semi-nomadic societies had far more freedom and power than women in other patriarchal cultures such as China or Persia. Especially in Turkic societies, feminine values were respected to certain degrees. In particular, matrilineality and female visibility can be observed during the formation stage of states, reflected, for instance, in the creation legends of the early Turks about a she-wolf as well as during occasions when a regent was needed to secure a peaceful succession to the throne (for the representation of female 
figures in the Qarakhanid arts, see Figs. 1 and 2). The Islamization of the Turks and their close relationship with sedentary societies had an influence on the position of women, but the first Turko-Islamic dynasties continued their seminomadic cultures, which might explain the political influence, economic independence, and high literary achievement of noble and upper-middle-class women in the Turkic societies of the tenth-twelfth centuries. These examples are well documented by Saljuq historians. However, the real power of women was often underrepresented in Muslim accounts due to the ideals applied to women in the Islamic world. ${ }^{58}$ This means that in reality, these women could have been even more powerful than they were described in sources. Qarakhanid women were no exception, but our knowledge about their roles in politics and society is limited due to the lack of sources on Qarakhanid history in general. At the same time, biographies of some Qarakhanid women can be found in Saljuq sources that may help to understand their image and place in the Turkic society.

The most famous Qarakhanid woman in history probably was Turkan Khatun, the queen consort of the Saljuq Sultan Malik Shah I. She was also regent for her son Mahmud I from 1092 to 1094 and attempted to become an official ruler of the Saljuq Empire. She was originally a Qarakhanid princess, the daughter of the Qarakhanid Khagan Tamghach Khan Ibrahim, and probably received a good education at her father's court. The Qarakhanids educated both boys and girls in bilig and adab (wisdom and good manners). ${ }^{59}$

Turkan Khatun was very ambitious and managed to gain political power and influence at court and in the army. The relationship between Turkan Khatun and Nizām al-Mulk, the vizier of the Saljuq Empire, reflected his views on women in politics and he doubtless had Turkan Khatun in mind in his portrait of female rule in Siyāsatnāma, when he criticized the harmful influence of women at court and their misleading advice to the rulers: ${ }^{60}$

The king's underlings must not be allowed to assume power, for this causes the utmost harm and destroys the king's splendor and majesty. This particularly applies to women, for they are wearers of the veil and have not complete intelligence. Their purpose is the continuation of the lineage of the race, so the more noble their blood the better, and the more

$5^{8}$ For this assumption and the women's position in the Saljuq period, see Hillenbrand, "Women in the Saljuq Period," 103-120.

59 Qutadghu bilig, trans. Dankoff, 187; for the Turkic text, see Qutadghu bilig, ed. and trans. Arat, vol. 1, $45^{2}$.

6o Bosworth, "The Political and Dynastic History," 77. 


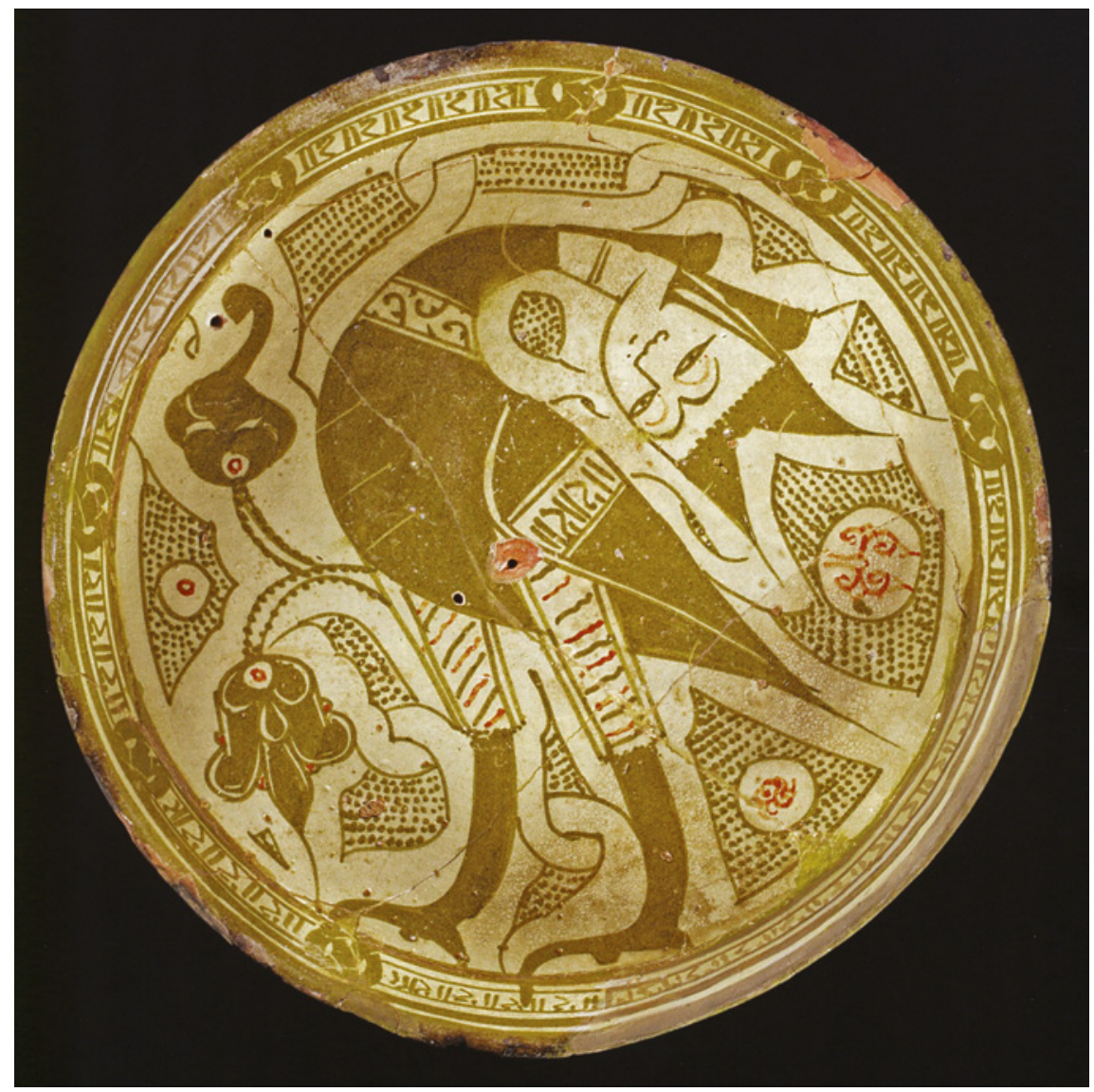

FIgURE 2 Qarakhanid Siren with a Female Face, Pottery Bowl from the Kanka site, Uzbekistan

(C) S. ILIASOVA, FROM ILIASOVA ET AL. 2016

chaste their bearing the more admirable and acceptable they are. But when the king's wives begin to assume the part of rulers, they base their orders on what interested parties tell them, because they are not able to see things with their own eyes in the way that men constantly look at the affairs of the outside world. ${ }^{61}$

The Saljuq historian al-Husaynī explained the reasons for Turkan Khatun's power and influence as her kind attitude towards soldiers, her descendancy

61 Siyāsatnāma, trans. Darke, 185. 
from the kings of the Turks of Afrasiyab, and her personal wealth. ${ }^{62}$ When her daughter married the Caliph of Baghdad al-Muqtadī and complained about his bad temper, she was returned to her home. ${ }^{63}$ This was certainly due to the Turkan Khatun's influence at court. When Malik Shah died, she kept his death secret and started to negotiate with the Caliph of Baghdad al-Muqtadī to assure the succession and defend herself against the other pretenders to the throne. She managed to ensure the khutba was issued in her son's name but she never succeeded in becoming the official ruler. ${ }^{64}$

The Qarakhanid poet and vizier Yūsuf Khāṣṣ Ḥājib, in his mirror for princes used almost the same words about women as the Saljuq vizier:

How many stalwart and manly men have been cut off at the root because of women? Many a man with ruddy cheeks and honor-lustered face has turned to earth because of women. Thousands of world-renowned and valiant men have been buried alive by women. Indeed, how is one to guard women at all?65

The Qarakhanid vizier may have had specific courtiers in mind when criticizing their damaging influence on men. Describing noblewomen, he denounced their long tongues and wrote that a man who chooses a wife for her nobility and status will be her slave. ${ }^{66} \mathrm{Ibn}$ al-Athīr mentioned occasions when Qarakhanid women ruled as regents or held political power at court. For instance, a wife of Bughra Khan ibn Qadir Khan killed his elder son and put her own son Ibrahim on the throne. ${ }^{67}$

Elite Turkic women were able not only to travel independently but also could be sent by a ruler to neighboring countries and personally meet with monarchs. Nizâm al-Mulk described a story of a Turkic woman at the Ghaznavid court who was well educated and could speak several languages. She was sent by Sultan Mahmud to Samarqand with a secret mission to steal a charter of the caliph sent to the Qarakhanid Khagan. The woman first arrived in Kashghar to buy Turkic slaves and commodities imported from China and Khotan, and

\footnotetext{
62 Akhbār al-dawla al-saljūqiyya, trans. Bosworth, 53.

63 Bosworth, "The Political and Dynastic History," 100-101.

64 Fatima Mernissi, The Forgotten Queens of Islam (Cambridge: Polity Press, 1993), 27-28.

65 Qutadghu bilig, trans. Dankoff, 187-188; for the Turkic text, see Qutadghu bilig, ed. and trans. Arat, vol. 1, 454.

66 Qutadghu bilig, trans. Dankoff, 186; for the Turkic text, see Qutadghu bilig, ed. and trans. Arat, vol. 1, 451 .

67 Al-Kämil fì al-ta'rīkh, ed. Tornberg, vol. 9, 211; Al-Kämil fı̀ al-ta'rīkh, trans. Bulgakov and Kamoliddin, 185 .
} 
then traveled further to Samarqand. She first met with the Khatun there and later with the Qarakhanid Khagan and presented them both with commodities brought from Kashghar. She introduced herself as the widow of a merchant and claimed that they had traveled around the world together but her husband died in Khotan on the way to China (Khitāy). There, a business partner of her husband advised her not to carry back the goods they were taking to China, so she decided to present them to the Khagan of Kashghar. After that, she was given to him as a wife, but he later also died and left her some capital. She introduced her son as a child of this second marriage and asked the Khagan to protect them. This gave her access to the court and a chance to steal the Caliph's charter. ${ }^{68}$ The story is probably apocryphal but it paints a vivid picture of Turkic women and their mobility in that period. Moreover, it also confirms that Khotan was a central point from where trade caravans to China were dispatched and that merchants traveled to China with their wives:

So he [Sultan Mahmud] supplied her with whatever she demanded in the way of money, jewels, robes, ornaments, animals, and provisions. This woman had a son of fourteen years old who was being educated at the hands of a teacher; she took the boy with her and set out from Ghazni to Kashghar. There she bought some Turk pages and bondmaids, as well as a large supply of choice goods imported from China [Khitāy] and Khotan, such as musk and various kinds of silk. Then she traveled in the company of merchants to Uzgend and went from there to Samarqand. Three days after her arrivals she went to pay her respects to the Khatun, offering a very handsome Turk bondmaid as a gift together with many choice things from India, Khotan and China; and saying, "My husband was a merchant; he used to travel throughout the world and take me with him; we were going to China, but when we reached Khotan he died. I turned back and came to Kashghar." 69

The story of this Turkic woman also states that women could join trade caravans, as she did when she was traveling from Kashghar to Uzgend and from there to Samarqand. This indicates that not all women in trade caravans were related to the merchants. There were some women among them who traveled independently for commercial purposes or even on a mission for their ruler.

Female envoys were not common in China, but records on some delegations can be found in Song sources. In particular, an official female delegation

68 Siyāsatnāma, trans. Darke, $154^{-158 .}$

69 Ibid, 155. 
that arrived at the Song court from the Women Kingdom (Nüren guo) was illustrated by the Song artist Li Gonglin (1049-1106) in his Wanfang zhigong tu (Portrait of Tributaries of the Myriad Regions)..$^{70}$ Descriptions of the Women's Kingdoms began to appear in Chinese sources starting in the sixth century. Envoys from kingdoms ruled by women were frequently mentioned from the Tang period onwards. The Song official Zhao Rugua recorded two Women's Kingdoms located in the southeast and the Western Sea. The latter had trade relations with Daqin (Baghdad) and Tianzhu (India). ${ }^{71}$ Wenxian tongkao recorded that the Western Women Kingdom (Xi Nü guo) was located to the west of Pamir. ${ }^{72}$ The exact locations of these kingdoms are unclear. The concept of "southeast" can be also viewed in a broader sense as referring to the territories from Southeast Asia to Australia. The Women Kingdoms are also often described as mysterious lands full of mythical and imaginary information.

Song sources also recorded a Buddhist nun who was dispatched as an envoy by the Khagan of the Ganzhou Uyghurs to the Song court in 1007:

景德四年冬十月戊午, 甘州回鶻可汗夜落紅遣尼法仙等來朝, 獻馬十 匹, 仍許法仙遊五臺山。尋又遣僧翟大泰來, 貢馬十五匹, 欲於京城 建佛寺祝聖壽, 求賜名額, 不許。73

On the day wuwu of the tenth month in winter of the Jingde era [December 7, 1007], Ganzhou Huigu Yelage kehan [Yaghlaqar Khagan of the Ganzhou Uyghurs] dispatched the nun Faxian and others to arrive at the court and present 10 horses, therefore the nun Faxian was permitted to travel to Wutaishan. ${ }^{74}$ Soon he also sent the monk Zhai [also pronounced as Di] Datai to arrive at the court and offer 15 horses; he wanted to build a Buddhist temple in the capital to wish a long life to the wise man [Emperor] and requested to grant an inscribed board with the name, but it was not allowed.

70 Wanfang zhigong tu 萬方職貢圖 [Portrait of Tributaries of the Myriad Regions], painted by Li Gonglin 李公麟 (1049-1106), retrieved from Freer Gallery of Art, Smithsonian Institution, Washington, D.C., Gift of Charles Lang Freer, F1911.18o. https://asia.si.edu/ object/Fr1911.18o/.

71 Zhu fan zhi, trans Hirth and Rockhill, 151.

72 Wenxian tongkao, 339: 2662-3.

73 Xu zizhi tongjian changbian, 67: 1501. This mission also appears in the section of Huigu in Song shi, 490: 14115. This was the second mission by the nun Faxian; her first was in 1004. For the text and translation, see Appendix 1.

Wutaishan is a sacred Buddhist site located in Qingshui, Shanxi Province, China. 
Biellenstein translated the word ni, which means Buddhist nun, as

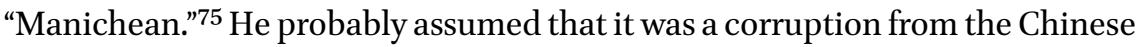
term mani referred to the Manichaeism. However, Faxian requested to travel to Wutaishan, which is a sacred Buddhist site. Manicheans often appeared in Song sources under the term waidao, meaning non-Buddhists and chicaishimo (vegetarian demon worshipers) and disregarded by the Song authorities. At the same time, Uyghur Khagans often appointed Buddhist monks who traveled between India and China and sent as envoys to the Song court. It is most plausible, therefore, that Faxian was a Buddhist nun.

During the early Song period, specifically in 1019, there were 230,127 officially registered Buddhist monks and 15,643 Buddhist nuns in China. ${ }^{76}$ Buddhist nuns were depicted in Song sources as dedicated practitioners and influential teachers and were under the patronage of the imperial family and local elites. Moreover, during the Song period, women were allowed to ordain female disciples and managed their monastic affairs independently, without being subordinate to monks. ${ }^{77}$ Apparently, they could also act as emissaries and lead official missions sent by the Uyghur Khagans to the Song court. Moreover, Khatuns of the Ganzhou Uyghurs also dispatched their own official missions to the Song court:

其年, 夜落紀、寶物公主及沒孤公主、乷溫宰相各遣使來貢。東封禮 成, 以可汗王進奉使姚進為寧遠將軍, 寶物公主進奉曹進為安化郎 將, 賜以袍笏。又賜夜落紇介甾。[...] 三年四月, 可汗王、公主及宰 相撒溫訛進馬、乳香。賜銀器、金帶、衣著、量錦旋襴有差。78

This year [1008], Yelage kehan [Yaghlaqar Khagan], Baowu Princess, Meigu Princess and zaixiang [Grand Councilor] Suowen [Saghun] each sent envoys to arrive with tribute. When the Dongfeng ${ }^{79}$ ceremony was finished, Yao Jin, the envoy of the Uyghur Khagan was appointed as ningyuan jiangjun [General Who Brings Repose to the Distance] and Cao Jin, the envoy of Baowu Princess as Anhua langjian [Commandant of Anhua] and they were granted robes and tablets. Also, Yelage kehan was granted armor and helmet. [...] On the fourth month of the third

75 Bielenstein, Diplomacy and Trade, $45^{2}$.

76 Hsieh Ding-hwa, "Buddhist Nuns in Sung China (96o-1279)," Journal of Song-Yuan Studies 30 (2000): 81 .

77 For the activities of Buddhist nuns during the Song period, see Hsieh, "Buddhist Nuns," $63-96$.

$7^{8}$ Song shi, 490: 14115-14117.

79 Dongfeng is Emperor Zhenzong's (967-1022) sacrifice to Heaven at Taishan in 1008. 
year [1025], kehan wang [Khagan King], Princess and zaixiang Sawene [Saghun] offered horses and frankincense. They were granted silverware, golden belts and brocade gowns, which varied according to their ranks.

Taking into account the position of Turkic elite women in their society and the presence of female envoys at the Song court, it can be assumed that women in Qarakhanid official delegations in China could have had their own missions. But women's histories and travels were compiled and written by men; therefore, we can rely only on what they decided to include in their accounts.

\section{Official Communication}

As a rule, Qarakhanid envoys had to present tribute and an official document known as a memorial (biao or biaozhang) to the Song emperor. The document was first checked by officials before it was forwarded to the throne. ${ }^{80}$ The response to Qarakhanid letters was usually an imperial proclamation or edict (zhao). Memorials and edicts were summarized in official and unofficial gazettes, a practice that had started during the Tang dynasty, if not earlier. It was not until the Ming period that it became common practice to publish collections of memorials. ${ }^{81}$ Therefore, not many documents of this type dating to the time before the Ming have survived, unless they were excerpted in standard histories or other compilations. To the best of my knowledge, no original letter written by the Qarakhanids to the emperors of the Song dynasty has survived. However, the content of some letters and extracts are recorded in Song sources.

Apparently, the original language of Qarakhanid letters was Turkic, which was later translated into Chinese by the envoy himself or by other interpreters. The first Qarakhanid envoy, Luo Siwen (Boyla Saghun), who arrived at the court of Emperor Zhenzong (r. 997-1022) in 1009, delivered a message from the Qarakhanid ruler Yusuf Qadir Khan, who requested from the Song emperor to send an official envoy. In this way, he probably sought to use the prestige of China and strength his status in the newly conquered territories. Luo Siwen started his report with the following formal expression:

8o Qingbo zazhi, 6: 53; Xu zizhi tongjian changbian, 295: 719o.

81 For various types of edicts and memorials in imperial China, see Wilkinson, Chinese History, $284-285$. 
臣萬里來朝, 獲見天日, 願聖人萬歲, 與遠人作主。 82

Your servant came to the court over ten thousand li to be able to see the light of day and wish the wise man [Emperor] to live ten thousand years and to take charge of people from afar.

The Qarakhanid envoy also informed the emperor that the road from Guazhou (Anxi) and Shazhou (Dunhuang) to Khotan was safer than it had been in earlier eras and asked to send the envoy "to pacify faraway places." 83 It can be assumed that the Qarakhanids were having trouble with the local population of Khotan, and asked for help in this matter by requesting an envoy. Emperor Zhenzong issued an edict instead of sending a messenger, saying that it would be the same. ${ }^{84}$ Unfortunately, the content of the edict was not recorded and it is not clear whether the Qarakhanids managed to get any support from the Chinese emperor.

The headings of the documents sent by two Qarakhanid rulers were preserved in Chinese translation in Qingbo zazhi (Miscellaneous Notes from the gate of Qingbo) written by Zhou Hui (b. 1126). The first memorial was presented to Emperor Shenzong by the Qarakhanid envoy, Commander Ashin, ${ }^{85}$ with the following heading:

\section{于闐國僂儸大福力量知文法黑汗王, 書與東方日出處大世界田地主漢 家阿舅大官家。86}

The letter from heihan king of the Yutian state [Qarakhan of Khotan], the clever, fortunate, powerful, civilized and rightful, ${ }^{87}$ to my uncle, Great Emperor of the Dynasty, the owner of fields and lands of the great world in the East, where the sun rises.

82 Song shi, 490: 14107. Also in Xu zizhi tongjian changbian, 71: 1598.

83 Song shi, 490: 14107 .

84 Xu zizhi tongjian changbian, 71: 1598; Song shi, 490: 14107.

85 The envoy was mentioned as "Axin from the barbarian division" ( fanbu Axin) in Xu zizhi tongjian changbian, 314: 7612 .

86 Qingbo zazhi, 6: 53. This heading was also provided in other Song sources, see Xu zizhi tongjian changbian, 314: 7612; Song shi, 490: 14109.

87 The expression "clever, fortunate, powerful," seems to be a Chinese translation of Turkic honorific epithets such as "Bilga, Qutlugh, Kuch/Kuchluk." I owe this comment to Pavel Lurje. For Turkic honorific epithets and reigned titles, see Skaff, Sui-Tang China and its Turko-Mongol Neighbors, 124-127. 
Commander Ashin, arrived at the court in 1081 and presented gifts from the Qarakhanid ruler. He stayed in Song China for two years and returned to the court in 1083. During his audience with the Chinese Emperor in 1083, Ashin told him that he had been sent away four years ago. This suggests that the envoy was dispatched by Tughril Qarakhan Yusuf ibn Sulayman (r. 1062-108o) or by his son Tughril Tegin 'Umar ibn Yusuf (r. 108o) in 1079/8o. The purpose of this letter was to inform the emperor that three previous delegations sent by the Qarakhanid ruler to the Song court had not returned. The Song emperor replied that he had summoned all the envoys and sent them back with gifts. The inappropriate addressing of the Chinese emperor as ajiu, "maternal uncle," and the word choice suggest that the heading of the memorial was translated by a non-Chinese interpreter. The envoy came to the court along with a guide from the Tsongkha kingdom, who served as an interpreter between the Qarakhanid envoy and the Song emperor. ${ }^{88}$ It was likely he who translated the memorial. I assume that Tsongkha interpreters were heavily involved in the Qarakhanid-Song diplomatic relations.

The heading of the second memorial included in Qingbo zazhi was probably sent by Arslan Khan Ahmad ibn Hasan (r. 1102-1128) to Emperor Huizong during the Zhenghe reign (1111-1118). It was also probably translated by Tsongkha interpreters. The text of the heading runs:

日出東方、赫赫大光、照見西方五百里國、五百國內條貫主黑 汗王, 表上日出東方、赫赫大光、照見四天下、四天下條貫主阿舅大 官家。89

The sun rises in the East, the splendid radiance illuminates the state of 500 li in the west, the letter from Tiaoguanzhu heihan wang [Tabghach Qarakhan king] of the state of 500 li90 to my uncle, Great Emperor of the Dynasty, Tiaoguanzhu and the whole world in the East, where the sun rises and the splendid radiance illuminates the whole world.

The Qarakhanid rulers who sent these memorials to the Song emperors could not justifiably use the term "maternal uncle" to refer to the Song emperors since the Qarakhanids did not have marriage alliances with the Song dynastic

88 Xu zizhi tongjian changbian, 314: 7612; Song shi, 490: 14109.

89 Qingbo zazhi, 6: 53. See also Document 4 in Appendix 2.

9o For the term "Tiaoguanzhu" that refers to Tabghāch, which was the name for China in the medieval Turkic world, see Huang Shijian 黄时鉴, Dong Xi wenliu shilun gao 東西文流 史論稿 [History of Cultural Interactions between East and West] (Shanghai: Shanghai guji, 1998), 11-15. 
members. ${ }^{91}$ Currently, there is no evidence in Chinese or Muslim sources that would confirm a "nephew-uncle relationship" between the Qarakhanids and the Song emperors. The original text, which was apparently in Turkic was almost certainly different from its Chinese translation. I believe that the Tsongkha interpreters who translated the original text applied the previous form that was used during the Tibetan Empire, when Tang princesses became cultural and political ambassadors between China and Tibet. ${ }^{92}$ This practice was not continued during the Song period, but Tsongkha rulers continued to use the expression of "maternal uncle" in their correspondence. ${ }^{93}$ Therefore, interpreters also applied this form when translating the Qarakhanid memorials. However, Huang Shijian suggested that the Qarakhanids originated from the Uyghurs, who had practiced marriage exchanges with the Tang emperors and addressed the Chinese emperor as "maternal uncle" in official correspondence. Therefore, the Qarakhanids could continue this practice in official communication with the Song emperors. ${ }^{94}$

The Chinese translation of the second letter was recorded in Tieweishan congtan (Collection of Talks from the Tiewei Mountain), written by the Northern Song official Cai Tiao (d. 1126). His work includes important information on the system of court administration in the Northern Song. In the heading of the Qarakhanid letter recorded by Cai Tiao, Arslan Khan Ahmad ibn Hasan was referred to as ajiu heihan wang (uncle Qarakhan King). ${ }^{95}$ This seems to be an error, as Huang Shijian also pointed out. ${ }^{96}$ This letter was also recorded by Zhang Shinan, a scholar of the late twelfth and early thirteenth centuries in his book Youhuan jiwen (Records of Official Travel). The author collected various types of correspondence used in the administrative court of the Song dynasty. The letter written by Arslan Khan Ahmad ibn Hasan was also included. In the heading of the letter the Qarakhanid ruler was mentioned as shizi heihan wang (Lion Qarakhan King), which refers to the Turkic title Arslan, meaning "lion."97

91 Tabā̄i' al-hayawān, ed. and trans. Minorsky, 15, for the Arabic text, see *3.

92 For the practice of exchanging princesses between imperial Tibet and Tang China, see Brandon Dotson, "The "nephew-uncle" relationship in the international diplomacy of the Tibetan Empire (7th-9th Centuries)," in Contemporary Visions in Tibetan Studies: Proceedings of the First International Seminar of Young Tibetologists, ed. Brandon Dotson, Tim Myatt, Kalsang Norbu Gurung, and Georgios Halkias (Chicago: Serindia, 2009), 223-38.

93 Qingbo zazhi, 6: $5^{2-53}$.

94 Huang, Dong Xi wenliu, 13.

95 Tieweishan congtan, 1: 9 .

96 Huang, Dong Xi wenliu, 12.

97 Youhuan jiwen, 5: 46. For the text and translation of the letter, see Document 4 in Appendix 2. 
The main purpose of the first Qarakhanid memorial was to obtain military support from the Song emperor to deal with a possible Muslim-Buddhist conflict in Khotan. Later the Qarakhanids also sought this support for confrontation with the Tanguts. ${ }^{98}$ Therefore, the communication between the Qarakhanids and the Song emperors encompassed much more than just formal presentations or expressing gratitude to the emperor.

Islamic sources recorded gifts and exchange of commodities between the Qarakhanids and other Islamic dynasties, which gives information not only on luxury goods coming from other parts of the Islamic world to the Qarakhanids but also on Chinese commodities that came through the Qarakhanids to the Islamic world, which could not always be obtained from Chinese sources. The latter mainly recorded goods coming to China from the Qarakhanid realm. The list of these gifts not only gives an idea of what a particular state was able to send but also illustrates what the merchants took with them as trade goods.

The Qarakhanids sent their own local products to Song China as well as items from other parts of the world. Among the presents that they brought to the Chinese emperor were animals such as dromedaries, horses, donkeys, and lions, as well as typical nomadic goods, such as saddles, bridles, and belts decorated with jade; a type of Central Asian brocade known as hujin (barbarian or foreign brocade) and flowered fabric; semi-precious stones such as jade, lapis lazuli, green nephrite, pearl, coral, amber and ivory; drugs and aromatics like castoreum, frankincense, costus root, clove, "dragon salt" (longyan), ${ }^{99}$ and minerals like ammonium chloride and mercury. ${ }^{100}$ The variety of these items demonstrates that the Qarakhanids established themselves as the main actors of international trade in this period.

Animals and nomadic goods were local Qarakhanid merchandise, except the lions, which were probably brought from Iran or India. The Qarakhanids also presented this animal to the Liao emperors. Figurines of foreign envoys and artists with lions discovered from Liao tombs resemble Central Asians in their dress and physical features. Lions are not native to China; even the

\footnotetext{
98 Song shi, 490: 14109.

99 It could also be a corruption of "dragon spittle" (longxian), which is ambergris that was transported to China from the Islamic world and used for perfumery and medicine. Zhu fan zhi, trans Hirth and Rockhill, 237.

100 Song shi, 490: 14108-14109.
} 
Chinese word for lion (shi) is believed to derive from the Persian word shīr. ${ }^{101}$ The name implies that the lion was introduced to China via Central Asia. Later myths and legends about lions entered the popular imagination and occupied a significant place in Chinese culture. The Chinese believed the lion brought good luck and kept evil spirits away. Carved stone and ceramic lions were often set up in pairs to guard shrines, temples, palaces, and private homes, a custom that spread to other parts of the Sinitic world (even as far as Vietnam) and persists to this day.

There are some typical Qarakhanid goods among the gifts that were transported from Central Asia to China by the Sogdians. The Qarakhanids were the main suppliers of Central Asian fabrics in China, especially of a type known as the above-mentioned "barbarian brocade," which was also known as xijin (western brocade). During the Tang, this type of fabrics was mostly brought to China by Sogdian merchants. ${ }^{102}$ In Chinese, Sogdians were mostly simply called $h u$, meaning "barbarians," or "foreigners." 103 Sogdian brocades have been found in many cities along the Silk Roads and were highly prized in China. Therefore, the term hujin continued to be used for Central Asian brocade in later periods.

The Chinese taste for stones has a long history. Jade is a culturally rich object that is highly prized in China and has been imported from Khotan since ancient times. Jade items continued to be one of the main trade commodities brought to China during the time of the Qarakhanids. ${ }^{104}$ During the Song period, only Khotanese jade was used for decoration of Imperial clothing and ritual objects. For instance, according to Youhuan jiwen, in earlier eras jade was brought from foreign countries such as Khotan and Kashghar and places within the empire as Lantian, Nanyang, and Rinan. But during the Song period, jade was found only in Khotan. ${ }^{105}$

Lapis lazuli (jinxingshi, literally "gold-star stone") and green nephrite (feicui, literally "kingfisher") were also known as "the Stones of Khotan" (Yutian shi) in Song China. ${ }^{106}$ Green nephrite was probably from the Qarakhanid realm, but

101 Laurence Picken, "Music for a Lion-Dance of the Song Dynasty," Musica Asiatica 4 (1984): 200-201.

102 Morris Rossabi, "The Silk Trade in China and Central Asia," in When Silk was Gold: Central Asian and Chinese Textiles, ed. James C.Y. Watt, and Anne E. Wardwell (New York: Metropolitan Museum of Art, 1997), 23.

103 Étienne de la Vaissière, Sogdian Traders: A History, trans. James Ward (Leiden: Brill, 2005), 131-133.

104 Rong and Zhu, "Cong jingong dao siyi," 193-195.

105 Youhuanjiwen, 5: 45-46.

106 Yunlin shipu, zhong juan: 19. For the association of jinxingshi with lapis lazuli and feicui with green nephrite and possibly also with another kind of lapis during the Song period, 
lapis lazuli came from the Badakhshan region in Afghanistan. The Qarakhanids obtained this item from the Ghaznavids, and together with pearls, corals, and ivory, brought them to China. All these items were among the diplomatic gifts that the Qarakhanids had received from the Ghaznavid Sultan.107

The Qarakhanids also obtained various types of drugs and aromatics from the Ghaznavids. ${ }^{108}$ However, not all of these items originated from India. The Ghaznavid conquest of India in the early eleventh century linked Arab, Persian and Indian traders with various parts of South Asia and China. The Ghaznavids established themselves as intermediaries for the Mediterranean-Chinese maritime trade and re-opened continental commercial routes connecting the cities of Central Asia.

Amber and castoreum were probably obtained by the Qarakhanids from the Volga Bulghars via Khwarazm. Baltic amber was also brought to China through the Sogdians, who obtained it from the Upper Volga. ${ }^{109}$ The Qarakhanids were well informed of the demand for this type of amber in China. Volga Bulghar merchants brought this merchandise, which was originally from Northern Europe to Khwarazm or even directly into the Qarakhanid realm. The Qarakhanids transported these items further to China during Liao and Northern Song times, connecting East Asia with the Fur Road networks.

Ammonium chloride and mercury can definitely be determined as having been brought from Central Asia, as there were many mineral mines there. Ammonium chloride, which was used in metallurgy and textile dying, was also often traded in China by Sogdian merchants. ${ }^{110}$

It is often difficult to find out which items were brought back by Qarakhanid merchants from China. The Qarakhanids received lavish rewards for their gifts from the Chinese emperors. In addition to luxurious Chinese garments, golden belts, jewels, silverware, and other ritual diplomatic gifts, they also received cash payments. Moreover, in order to foster economic relations with the Qarakhanids, the emperors reimbursed travel costs and provided lodging for the envoys. ${ }^{111}$ The Qarakhanids sought to obtain Chinese commodities that were highly prized in the Islamic world. These items were not only circulated in trade but also often presented to allied rulers. For instance, among the Qarakhanid diplomatic gifts to the Ghaznavids were Chinese vessels and

see Edward H. Schafer, Tu Wan's Stone Catalog of Cloudy Forest (Berkeley: University of California, 1961), 89-9o.

107 Kitāb al-Yamin̄ī, trans. Reynolds, 316; Zayn al-akhbār, ed. Ḥabībī, 188.

108 Ibid.

109 de la Vaissière, Sogdian Traders, 39, 175, 252-253.

110 de la Vaissière, Sogdian Traders, 134, 174; Hansen, The Silk Road, 101-102.

111 Song shi, 490: 14108-14109. 
fabric that may be identified as Song porcelain, silk, brocade, and other types of Chinese fabrics. ${ }^{112}$ The Qarakhanids also presented to the Ghaznavid Sultan a Chinese item called dārkhāshāk.113 This term could be an inaccurate combination of the Persian words dāru (medicine, drug) or $d \bar{a} r$ (wood), and khāshāk (leaves, sprigs). The term could refer to a kind of Chinese medicine as well as to Chinese tea. The Qarakhanids dispatched their envoys from Khotan to Kaifeng via trade roads known as "the Ancient Tea Horse Road" that had connected southwest China and Tibet since the Tang period.114

\section{Roads, Itineraries and Maps}

Details on the road and territories between the Qarakhanid realm and China were provided by Qarakhanid ambassadors at the Chinese court. Qarakhanid envoys not only reported on the content of official letters and presented gifts but they were also interviewed on roads and territories between their country and China and served as a source of knowledge about the Western Regions. One of these interviews, which took place in 1083 between Emperor Shenzong and the Qarakhanid commander Ashin, is included in Xu zizhi tongjian changbian. The Qarakhanid envoy met with the emperor in Yanhe dian, a Hall of the Imperial Palace, in Kaifeng:

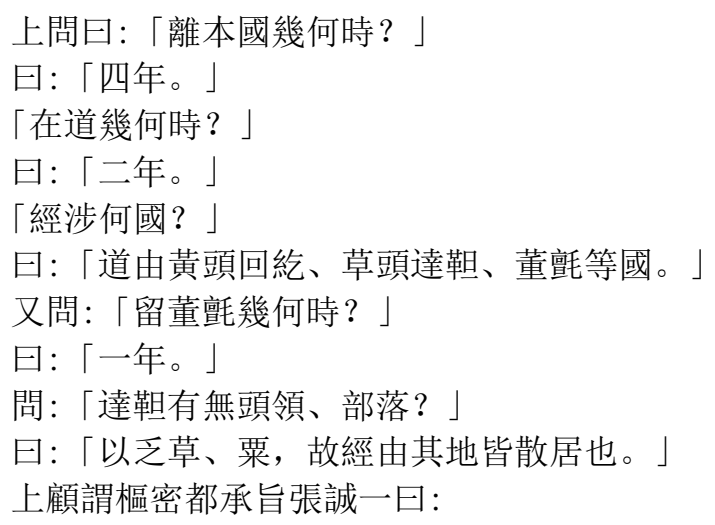

上問曰：「離本國幾何時？」

曰:「四年。」

「在道幾何時?」

曰:「二年。」

「經涉何國?」

曰:「道由黃頭回紇、草頭達靼、董氈等國。」

又問:「留董嘎幾何時？」

曰:「一年。」

問：「達靼有無頭領、部落？」

曰：「以乏草、粟，故經由其地皆散居也。」

上顧謂樞密都承旨張誠一曰:

112 Kitāb al-Yamin̄ī, trans. Reynolds, 178.

113 Zayn al-akhbār, ed. Habībī, 189. For the English translation, see Zayn al-akhbār, trans. Bosworth, 95.

114 For Qarakhanid relations with Tibet, see Chapter 4; for the Qarakhanid tea trade, see Chapter 6. 
「達靼在唐與河西、天德為鄰, 今河西、天德隔在北境。自太祖朝嘗 入貢,

後道路阻隔, 貢奉遂絕。」

又問：「嘗與夏國戰者，豈此達靼乎？」

曰:「達靼與李氏世雔也。」

又問：「道由諸國，有無抄略？」

曰:「惟懼契丹耳。」

又問：「所經由去契丹幾何里？」

曰:「千餘里。」115

The Emperor said: "When did you leave your state?"

The envoy replied: "Four years ago."

The Emperor: "How long have you been traveling?"

The envoy: "Two years."

The Emperor: "Which states did you pass through?"

The envoy: "The road was through Huangtou Huihe [Yellow-Head

Uyghurs], Caotou Dada [Straw-Head Tatars], Dongzhan [Tsongkha] and other states."

The Emperor also said: "How long did you stay in Dongzhan?"

The envoy: "One year."

The Emperor: "Do the Dada have headmen and tribes?"

The envoy: "Due to the lack of grass and grain, in their lands that I passed they all live scattered."

The Emperor turned around and addressed to Zhang Chengyi, shumidu chengzhi [Military Affairs Chief Recipient of Edicts]: "The Dada were located near Hexi [Hexi Corridor] and Tiande [Bayannur] during the Tang. Now Hexi and Tiande are blocked beyond the northern frontiers. From the reign of Emperor Taizu [96o-976] they offered tribute, but later the road was separated and it was immediately discontinued."

The Emperor also asked: "Are they those Dada who once had a war with the Xia state [Tanguts]?"

The envoy replied: "Dada and the Li dynasty are sworn enemies."

The Emperor: "Are there bandits on the road through all these countries?" The envoy: "We were only afraid of the Qidans [Khitans]."

The Emperor: "How many $l i$ is it from the places you have passed through to the territories of the Qidans?"

The envoy: "More than one thousand li."

115 Xu zizhi tongjian changbian, 335: 8061. An abridged version of this interview is also found in Song shi, 49o: 14109 and Song huiyao jigao, Fanyi 4: 17. 
This short interview not only provides many insights into the roads that connected China and the Qarakhanid realm but also gives a general view of Qarakhanid diplomacy in the east. The road from Khotan to China had been in existence since ancient times and was located in the trade routes known to historians as the Southern Silk Road. The road from Khotan to Tang China through Tibet was also used by Sogdian merchants prior to the Qarakhanids. ${ }^{116}$ The Qarakhanid envoy stated that he traveled for two years from Khotan to Kaifeng. However, he also mentioned that he stayed in the territory of Tsongkha for one year. Therefore, it can be assumed that the road from Khotan to Kaifeng through the territories of the Uyghurs, Tatars and Tsongkha took about one year to traverse. The first Qarakhanid envoy, who came to the Song court in 1009 also informed the court that he traveled for a year, passing through the territories of the Guazhou and Shazhou. However, he was not sure of the exact length of the route. ${ }^{117}$ The envoy from the Khotan kingdom, who arrived at the Song court in 961 stated that their country was located 9900 li away from the capital of the emperor. He also reported that to the southwest of Khotan lay Pamir (Congling) and India (Poluomen), in the south was Tibet (Tubo), and in the northwest was Kashghar (Shule).118

The Qarakhanid ambassador Ashin arrived at the Song court together with the envoy from Fulin, which refers to Asia Minor. The Fulin mission was also accompanied by the Qarakhanids in $1091 .{ }^{119}$ The Fulin envoy provided a more detailed itinerary, recounting the journey from Anatolia to China through Khotan. ${ }^{120}$ The itinerary described by the Qarakhanid commander Ashin during the interview should refer to the Qinghai Road, which is discussed in Chapter 6.

The Qarakhanid scholar Mạmmūd al-Kāshgharī illustrated his work with a world map centered on the main capital of the Qarakhanids, the ancient city of Balasaghun in present-day Kyrgyzstan. In his world map, he depicted different places on the road from Khotan to Song China, which he named Māșinn. The first part of the road also went from Khotan to Shazhou (Shānjū), which is Dunhuang, through the city of Cherchen. Then it turns to the lands of the Uyghurs in Turfan. The last destination before arriving in China was the city of Khātūn sinī, which according to Mạ̣mūd al-Kāshgharī, was located between the regions of the Tanguts and that of the Khitans (al-Ṣin). However, it is not

\footnotetext{
116 de la Vaissière, Sogdian Traders, 144-147.

117 Song shi, 490: 14107.

118 Song shi, 490: 14106.

119 Xu zizhi tongjian changbian, 455: 10906.

120 For the road used by the envoy from Anatolia, see Chapter 5 .
} 
clear whether this road passed through the land of the Khitans. According to Mahmmūd al-Kāshgharī, a journey from the land of the Khitans (al-Ṣinn) to Song China (Māșinn) in the eleventh century took four months. ${ }^{121}$ It can be assumed that the Qarakhanids also used the road through the land of the Khitans, at least during the period of the marriage alliance between the Qarakhanids and the Khitans in 1021. ${ }^{122}$ However, the Qarakhanid envoy clearly stated that they were afraid of the Khitans, who were more than one thousand $l i$ away from the territories they passed. This statement may hint at possible conflicts between two polities in this period or the willingness of the Khitans to control the land roads and trade between the Qarakhanids and Song China.

As the Qarakhanid envoy clearly pointed out, the embassy was allowed to pass through the territories of the Uyghurs, the Tatars, and the Tsongkha kingdom, which indicates that close relations existed between them. The remarks by the Qarakhanid envoy on the Tatars and their conflict with the Tanguts demonstrate that the Qarakhanids were also well informed about the political situation in the territories of their eastern neighbors. Moreover, it shows that the Qarakhanid knowledge of the outside world was much broader than may be suggested from the first Turkic world map drawn by the Qarakhanid scholar Maḥmūd al-Kāshgharī.

Maḥmūd al-Kāshgharī did not mention his informants, and it can be only assumed that he most likely obtained knowledge about roads to China from Qarakhanid envoys and merchants. At the same time, Chinese texts recorded Qarakhanid envoys as cartographers and sources of knowledge about the western territories in China. For instance, according to the imperial edict issued on May 23, 1083 Emperor Shenzong ordered to dispatch an envoy to the Tatars using the map drawn by the Qarakhanid ambassador Ashin:

詔：「于闐大首領畫到達靼諸國距漢境遠近圖, 降付李憲。」以嘗有 朝旨委憲遣人假道董䡀使達靼故也。123

Imperial Edict: "The main chieftain of Yutian is to draw a map of distances of the all Dada [Tatars] states from the Han borders; it should be sent and given to Li Xian." Li Xian was appointed as envoy and sent to the Dada via Dongzhan [Tsongkha], therefore, [the map was given to him].

121 For the terms al-Ṣīn and Māṣīn resp. Khātūn sinī, see Dīwān lughāt al-Turk, trans. Auezova, 424, 843, 1289-129o. For the map and cities, also see Albert Herrmann, "Die älteste türkische Weltkarte (1076 n. Chr.)," Imago Mundi 1, no. 1 (1935): 22-4.

122 Liao shi, 16:189.

123 Xu zhizhi tongjian changbian, 335: 8063; Song huiyao jigao, Fanyi 4: 17. 
Information provided by the Qarakhanid envoys could be used in major maps of the Song dynasty. For instance, Qarakahnid territories were depicted in the Song dynasty map Huayi tu (Map of Chinese and non-Chinese Countries) that was engraved as a stone stele in 1136. It is the earliest surviving map of China that depicts its neighboring territories. ${ }^{124}$ The map was first studied by Edouard Chavannes, who analyzed the place names and dates cited on the map and pointed out that it was initially drawn between 1043 and 1048. Moreover, he assumed that the author of the map was probably a foreigner due to some misuse of the era durations and place names depicted on the map. Chavannes suggested that the map was created by a Khitan author because the Khitan Empire was labeled as Da Liao (Great Liao). ${ }^{125}$ However, it is clear that it was not the effort of just one person. The author most likely worked with a group of cartographers that included travelers and foreign envoys.

I assume that information provided by Qarakhanid envoys was involved in the map-making process. The most remote western territory that was drawn on the map is the Qarakhanid realm. The map depicted the Qarakhanid major cities such as Yutian (Khotan), Shache (Yarkent), Shule (Kashghar) and Suiye (Suyab). Other places in the Western Regions were included in the list of countries on the left side of the map.

The depiction of Suyab, which is present-day Ak-Beshim on the eleventhcentury Song map, can lead to further discussions about its abandonment. Suyab, also known as Ordukent, was the capital of the Western Turk Khaganate. After the fall of the Khaganate, Suyab became one of the Four Garrisons of Anxi Protectorate of the Tang Empire. In 766, Suyab was occupied by the Qarluqs and served as the political center. Later it became one of the capitals of the Qarakhanids. Recent archaeological excavations in Ak-Beshim have demonstrated that the city was abandoned at the end of the tenth century or the beginning of the eleventh century at the latest. The city was displaced by Balasaghun, which is located 5 kilometers south of Ak-Beshim in presentday Burana. ${ }^{126}$ At the same time, the Chinese map that was created between 1043 and 1048 depicted Suyab. It was probably, introduced as the center of the Khaganate by Qarakhanid informants. However, according to the Chinese

\footnotetext{
124 Hua yi tu 華夷圖 [Map of Chinese and Non-Chinese Countries, 1136], retrieved from the Library of Congress, https://www.loc.gov/item/gm71005081/.

125 Edouard Chavannes, "Les deux plus anciens spécimens de la cartographie chinoise," Bulletin de l'École française de Extrême-Orient 3, no.2 (1903): 216.

126 Massashi Abe, "Results of the Archaeological Project at Ak Beshim (Suyab), Kyrgyz Republic from 2011 to 2013 and a Note on the Site's Abandonment," Intercultural Understanding 4 (2014): 15 .
} 


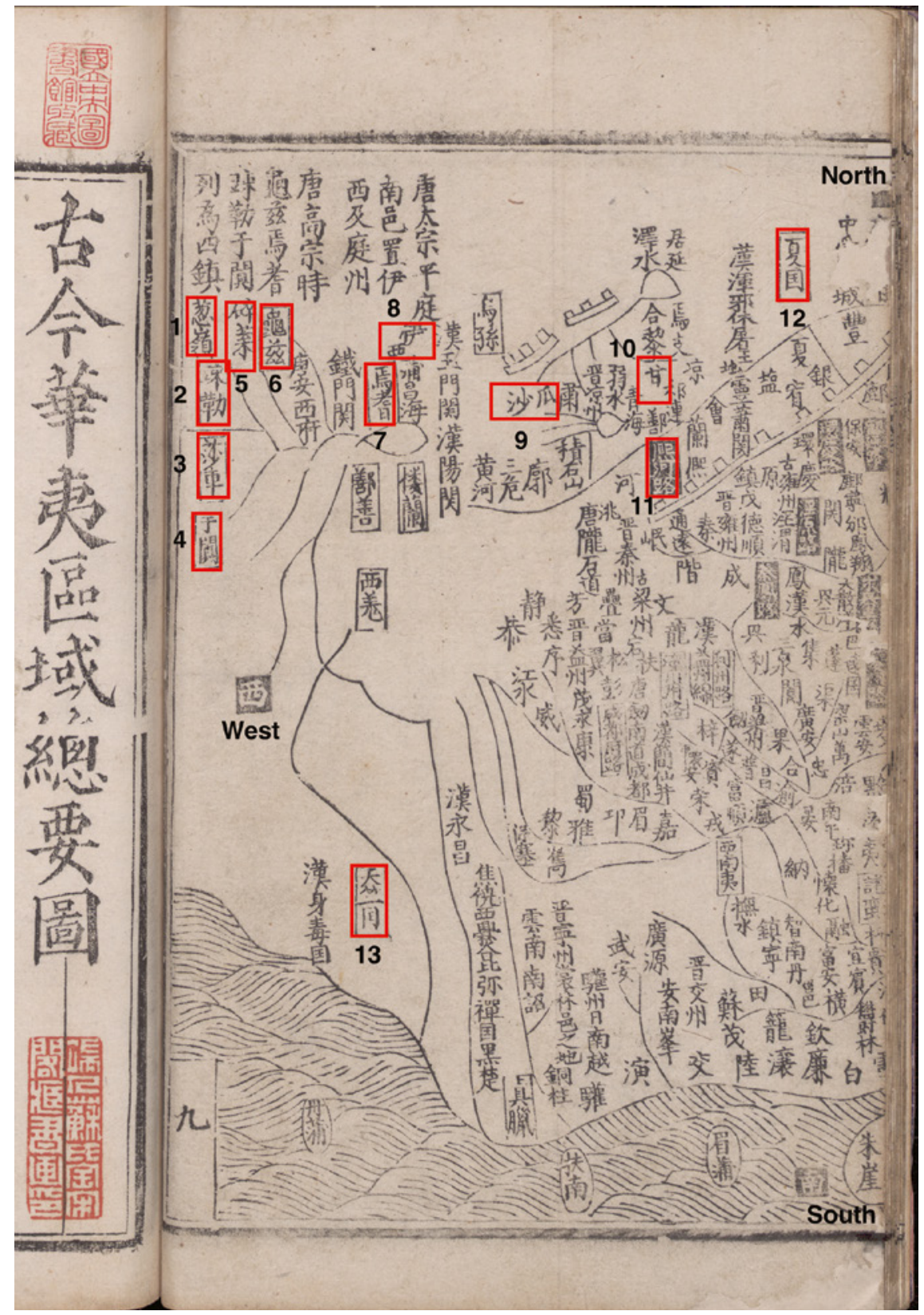

FIGURE 3.1 Song China and the Western Regions, from General Map of Chinese and Non-Chinese Territories in the Past and Present in Lidai zhili zhizhang tu, 113os, Ming dynasty print edition COURTESY OF THE NATIONAL CENTRAL LIBRARY, TAIWAN, NO. 04161

1. Congling (Pamir) 2. Shule (Kashghar) 3. Shache (Yarkent) 4. Yutian (Khotan) 5. Suiye (Suyab) 6. Qiuci (Kucha) 7. Yanqi (Karashahr) 8. Yizhou and Xizhou (Qomul and Turfan) 9. Shazhou and Guazhou (Dunhuang and Anxi) 10. Ganzhou (Zhangye) 11. Xizhou and Hezhou Circuit 12. Xia guo (Tanguts) 13. Tianzhu (India) 


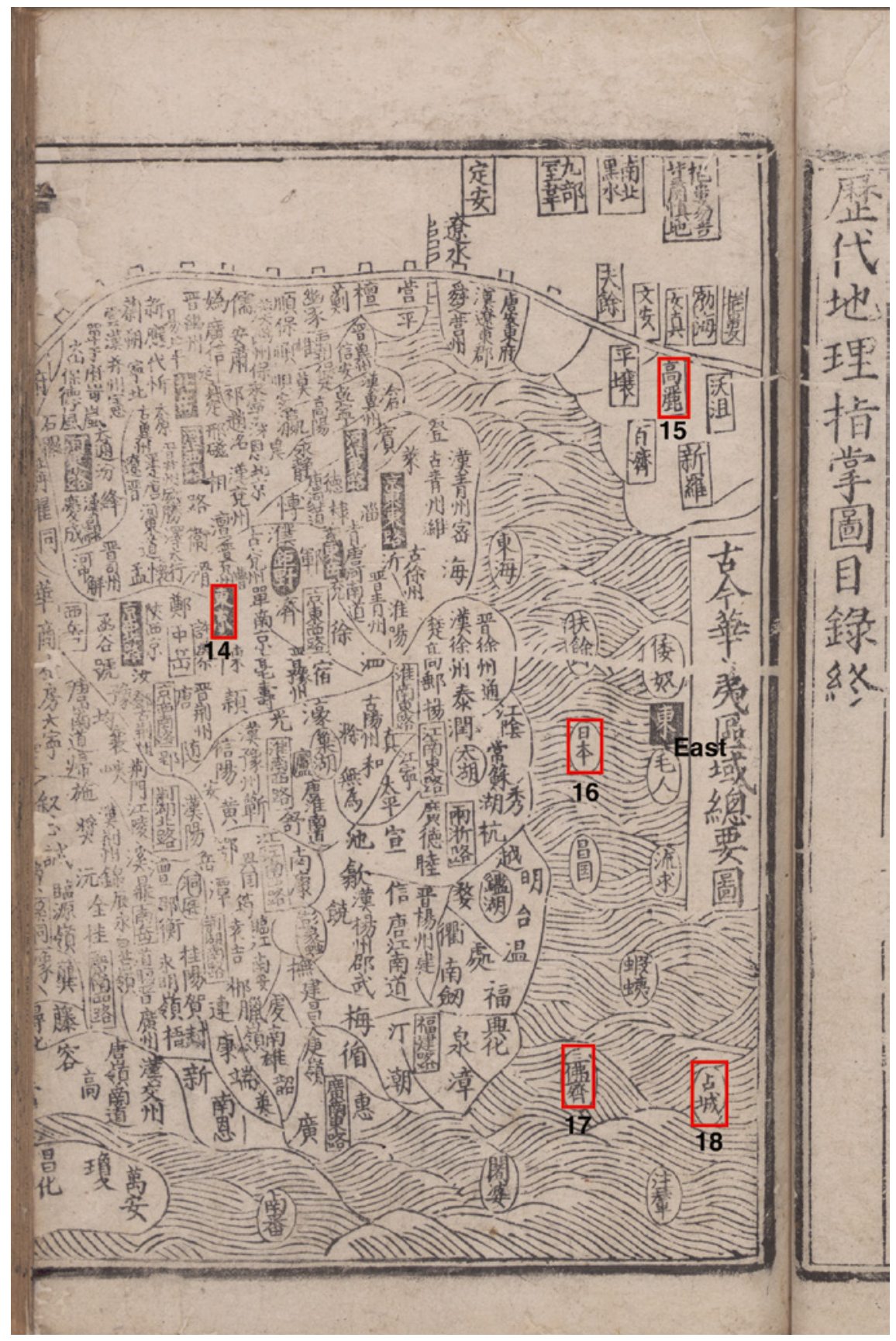

FIGURE 3.2 Song China and the East, from General Map of Chinese and Non-Chinese Territories in the Past and Present in Lidai zhili zhizhang tu, 113os, Ming dynasty print edition

COURTESY OF THE NATIONAL CENTRAL LIBRARY, TAIWAN, NO. 04161 14. Dongjing (Kaifeng) 15. Gaoli (Korea) 16. Riben (Japan) 17. Sanfoqi (Srivijaya) 18. Zhancheng (Champa) 
official sources, the first Qarakhanid envoy arrived in 1009 and then there were no missions from the Qarakhanids in the period from 1025 to 1063. It means that the Chinese collected the relevant information on the Qarakhanid territories between 1009 and 1025 . Therefore, it can be concluded that Suyab continued to be used as the capital of the Qarakhanids at the beginning of the eleventh century.

Hua yi tu was used as the main source for other maps during the Song dynasty. For instance, the same Qarakhanid cities also appeared in Gujin Huayi quyu zongyao tu (General Map of Chinese and non-Chinese Territories in the Past and Present).

This map was included in the earliest historical atlas in China Lidai dili zhizhang tu (Handy Geographical Maps through the ages) created during the Northern Song period. The earliest extant printed edition is dated to the 113os, and is currently stored in Toyo Bunko in Tokyo. This edition was compiled by the Song scholar Su Shi (1037-1101). The exact date and author of the original publication are unknown. It is assumed that the first edition was published at the end of the eleventh century during the Northern Song period and compiled by cartographer Shui Anli (d. 1099). ${ }^{127}$ Figures 3.1. and 3.2. are images from the Ming dynasty edition of the Song printed edition compiled by Su Shi and held in the Central National Library in Taiwan. ${ }^{128}$

\section{9}

\section{Missions to Hangzhou?}

When the Jurchens conquered most of northern China, the Song imperial family was forced to retreat south from its original capital in Kaifeng and re-establish their court in Hangzhou, which was renamed Lin'an (literally, "Approaching Peace"). Chinese sources did not record missions from Khotan during the Southern Song. The Jurchens conquered the Song capital Kaifeng in 1126 and the Tsongkha kingdom in $1182 .{ }^{129}$ This political situation interrupted

127 The facsimile edition of the Lidai dili zhizhang tu Song edtition held at the Toyo Bunko was published as Songben lidai dili zhizhang tu (Shanghai: Shanghai chubanshe, 1989). For the detailed discussion of the Atlas and the General Map of Chinese and non-Chinese Territories in the Past and Present, see Hilde de Weerdt, "Maps and Memory: Readings of Cartography in Twelfth- and Thirteenth-Century Song China," Imago Mundi 61, no. 2 (2009): 158. The same author. Information, Territory, and Networks: The Crisis and Maintenance of Empire in Song China (Cambridge: Harvard University Press, 2015), 125-143.

128 Lidai dilizhizhang tu, Ming edition, 8, 9.

129 Petech, "Tibetan Relations," 178. 
Qarakhanid-Song relations. Moreover, the Western and Eastern Qarakhanids became the subjects of the Western Liao (the Qara Khitai) after the 113os. ${ }^{130}$ This affected their image in the Sinitic world and they probably were seen generally as Dashi, meaning Muslims. The Qarakhanid realm was also viewed as a part of the Western Liao empire, which was mentioned as Dashi after the name of its founder, Yelü Dashi. ${ }^{131}$ Therefore, it is not easy to distinguish the Qarakhanids in twelfth-century Chinese records from other Muslim states or the Western Liao.

Qarakhanid merchants most likely had the opportunity to trade in the territories of the Uyghur Idiquts in Turfan, who were also incorporated into the Western Liao Empire. How far-reaching was the Qarakhanid eastern trade during the twelfth century? Michal Biran pointed out that Qarakhanid merchants had their stations in the Tangut territories and some delegations even passed further, to Jin China. ${ }^{132}$ Indeed there are some data confirming Tangut-Qarakhanid and Jurchen-Qarakhanid contacts. For instance, a Qarakhanid coin dated 1056/57-1057/58 was unearthed from the Tangut site in Lingwu County in Ningxia during the excavations conducted by the Institute of Archaeology of the Chinese Academy of Sciences in 1984-1986.133 Moreover, the collection of Tangut laws Tiancheng gaijiu xinding lulling (Revised and Newly Endorsed Code for the Tiancheng Era) described regulations applied to foreign envoys and merchants from countries such as Dashi and Xizhou (Turfan). ${ }^{134}$ The Tangut Code was compiled during the Tiancheng era (1149-1169). Therefore, Dashi here could refer both to the Qarakhanids and the Qara Khitai.

The official history of the Jin dynasty recorded a mission form the Qara Khitai realm that most likely refers to the Qarakhanids:

大定中, 回紅 移習覽三人至西南招討司貿易, 自言: 「本國 回紀 鄒 括番部, 所居城名骨斯訛魯朵, 俗無兵器, 以田為業, 所獲十分之一

130 For the political history of the Western Liao, see Biran, The Empire of the Qara Khitai.

131 For the representation of the Qarakhanids in the Sinitic world during the twelfth century, also see Biran, The Empire of the Qara Khitai, 138.

132 Biran, "The Qarakhanids' Eastern Exchange," 582.

133 Zhang Lianzi 张连喜 and Ma Wenkuan 马文宽, “Ningxia Lingwu Ciyaobao chutu qianbi ji moshu «diao » zi cipian 宁夏灵武磁窑堡出土钱币及墨书“吊”字瓷片 [Coins and a Ceramic Chip with Inscription “diao” Unearthed from the Ciyao Fort in Lingwu, Ningxia]," Kaogu 考古 12 (1991): 1105 .

134 Tiancheng gaijiu xinding lüling, 7: 284-285. 
輸官。耆老相傳, 先時契丹至不能拒, 因臣之。契丹所居屯營, 乘馬 行自旦至日中始周匝。近歲契丹使其女壻阿本斯領兵五萬北攻葉不輦 等部族, 不克而還, 至今相攻未已。」詔曰:「此人非隸朝廷番部, 不須發遣, 可於咸平府舊有 回紅人中安置, 冊令失所。」135

During the Dading era [1161-1189] three men headed by Huihe Ixilan arrived at the southwestern Bandit-Suppression Commission for trade and said: "Our state is the Huihe Zoukuo tribe, the name of the city where we are located is Gusieluduo [Kuz-Orda, i.e., Balasaghun], there are no weapons in our custom, we work on the fields and give one-tenth of our harvest to the officials. Our old men passed on that during the previous times when the Qidans [Khitans] arrived, people were unable to resist and therefore submitted to them. The encampment in which the Qidans reside can be circled if one rides a horse from daylight to the beginning of midday. In recent years, the Qidans sent the son-in-law Abensi led by $5^{\mathrm{o}, 000}$ men to attack the Yebulian and other tribes in the north, he was unable to overcome them and returned, and to this day the attacks on each other have not been yet finished. The Imperial Edict said: "These people do not belong to the foreign tribes of the imperial court and there is no need to send them; they can be emplaced in Xianpingfu [Kaiyuan] among the Huihe that have been there since ancient times; do not order them to lose their homes."

These merchants came from Balasaghun and belonged to the "Uyghur Zoukuo" group. Liu Yingsheng suggested that Zoukuo could refer to the Chigil component of the Qarakhanids and concluded that this record may confirm the Chigil hypothesis of the Qarakhanid ruling elite origin. ${ }^{136}$ The most interesting is that the Jin source applied the term Huihe for the Qarakhanid mission. This means that the Qarakhanids were known not only under the term Dashi but also as Huihe during the Jurchens. However, it does not help to distinguish the Qarakhanids in Chinese sources of the twelfth century.Jin shi recorded eleven missions sent by Huigu/Huihe from 1127 to 1172 .

135 Jin shi, 121: 2637 .

136 Liu, "A Century of Chinese Research," 121. 
TABLE 2 "Uyghur" missions to the Jin Court

\begin{tabular}{|c|c|c|c|c|}
\hline & Date & Sender & Envoy & Purpose \\
\hline 1. & $\begin{array}{l}\text { March 11, } 1127 \\
J S 3: 5^{6}\end{array}$ & Heli Khagan & not specified & tribute \\
\hline 2. & $\begin{array}{l}\text { November 20, } \\
1127 \\
J S 3: 58\end{array}$ & Huolasan Khagan & not specified & tribute \\
\hline 3. & $\begin{array}{l}\text { September 10, } 1131 \\
\text { JS 3: } 63\end{array}$ & Uyghur Weiyu & not specified & tribute \\
\hline 4. & $\begin{array}{l}\text { October } 8,1131 \\
J s \text { 3: } 63\end{array}$ & $\begin{array}{l}\text { Hezhou (Turfan) } \\
\text { Uyghurs }\end{array}$ & not specified & $\begin{array}{l}\text { The Uyghurs captured } \\
\text { people of Yelü Dashi } \\
\text { named Saba, Dili, } \\
\text { Tudie and came to } \\
\text { present them to the } \\
\text { Jin court. }\end{array}$ \\
\hline 5 . & $\begin{array}{l}\text { September 15, } 1138 \\
\text { JS 4: } 73\end{array}$ & Uyghurs & not specified & tribute \\
\hline 6. & $\begin{array}{l}\text { July } 27,1142 \\
\text { JS 4: } 79\end{array}$ & Uyghurs & not specified & tribute \\
\hline 7 . & $\begin{array}{l}\text { March 21, } 1144 \\
\text { JS 4: 80; 121: } 2637\end{array}$ & $\begin{array}{l}\text { Uyghurs } \\
\text { (neighbors of } \\
\text { Yelü Dashi) }\end{array}$ & not specified & congratulatory \\
\hline 8. & $\begin{array}{l}\text { January } 27, \\
1153 \\
J S 5: 100\end{array}$ & Uyghurs & not specified & tribute \\
\hline 9. & $\begin{array}{l}\text { November, } 1156 \\
\text { Js 5: } 107\end{array}$ & Uyghurs & Yinshuwulonggu & tribute \\
\hline 10. & $\begin{array}{l}\text { In the third month, } \\
1172 \\
J S 7: 156\end{array}$ & Uyghurs & not specified & tribute \\
\hline 11. & $\begin{array}{l}\text { In the fourth month, } \\
1172 \\
J S 7: 15^{6}\end{array}$ & Uyghurs & not specified & tribute \\
\hline
\end{tabular}

The table demonstrates that Jin sources often did not specify the exact origin of the missions sent by the so-called "Uyghur" rulers. The term "Uyghur" was used in a wider sense in Jin China and also applied to the Qarakhanid realm. It means that in theory some of these missions could be dispatched 
by the Qarakhanids. The term "Uyghur" was also used to refer more generally to Central Asia during the Mongol conquest of the Khwarazmian Empire. For instance, the Khwarazmshahs were recorded as "Uyghurs" in Chinese sources of that period. ${ }^{137}$ It can be concluded that from the twelfth century the term "Uyghur" could refer to Central Asia in general.

To sum up, the Qarakhanids were known as Dashi in Tangut sources and as Huigu/Huihe in Jin sources. Dashi could also refer to the Qara Khitai, as well as Huigu/Huihe to the Uyghurs. Therefore, often the Qarakhanids cannot be identified except in a few rare cases when more detailed descriptions are provided.

Qarakhanid relations with the Southern Song are questionable, but Qarakhanid commodities were able to pass further to Song China through the Tanguts, and Chinese merchandise was indeed transported to Central Asia. For instance, specimens of Song and Jin porcelain ceramics of the Qingbai, Longquan, and Ding types were unearthed in the layers of the Afrasiyab site dated to the second half of the twelfth century. ${ }^{138}$ The Qarakhanids were probably referred to by other names in Southern Song sources that may appear during further investigations. Therefore, Qarakhanid relations with the Southern Song and the Jin empires in the twelfth century is a field that remains to be studied, requiring more archaeological data as written sources do not provide much information.

The Qarakhanid Khaganate appeared in Song dynasty sources from the tenth century and was initially known after the name of its capital as Shule (Kashghar). The Chinese were aware of military confrontations between the Qarakhanids and the Khotan kingdom during the second half of the tenth century. Later when Khotan was incorporated into the Khaganate, the Qarakhanids gained control over the main passages of the Silk Road, which gave them a possibility to initiate diplomatic contacts with Song China. The Qarakhanids used Khotan as the main trade market for Chinese goods, and it also served as a midpoint for official delegations and trade caravans sent by the Khagans to Song China. For this reason, the Qarakhanid Khaganate started to be associated with Khotan and was known under this name in Chinese records from the very beginning of the eleventh century up to the twelfth century.

137 The case of the Khwarazmshahs is discussed in Chapter 5 .

138 Sokolovskaia and Rougeulle, "Stratified Finds of Chinese Porcelains," 91-96. 
Qarakhanid official missions to Song China were mostly sent for commercial purposes and could also serve the military interests of both polities. The Khagans appointed high-ranking military officials and dynastic members as envoys known in China as banci (also spelled as banca) to lead diplomatic delegations and trade caravans to China. The Qarakhanids also offered military service in the frontiers of the Song Empire. At the same time, the Qarakhanid Khagans sought to form an alliance with the Song in the eastern borders mainly against the Tanguts. The hopes of the Qarakhanids for military support were not fulfilled, however, due to the weakness of the Song monarchs in this matter. But commercial relations with Northern Song China became a basis of the Qarakhanid economy, which brought them high prestige in international trade networks in the eleventh-century world.

Chinese texts recorded the presence of women in the Qarakhanid delegations, and they also participated in court ceremonies. Muslim sources confirm that elite women in eleventh-century Turkic society could independently join trade caravans, travel to remote territories, including China, and even meet with rulers personally.

What emerges from the list of the Qarakhanid commodities transported to Northern Song China is that Qarakhanid trade was not specialized and they traded everything of value in China. They transported commodities from Turkistan, Iran, India, Arabia, and Europe to obtain Chinese fabrics, medicine, precious metals, and porcelain.

The Qarakhanid Silk Roads to China ran in two directions: the Hexi Corridor Road and the Qinghai Road. This helped to maintain access to the Chinese market during the Song-Tangut conflict. The diplomacy and commerce of the Qarakhanids along the Silk Roads linked Central Asia not only with China but also Tibet and India through the network of the Southern Silk Road. It facilitated knowledge exchange between Central Asia and China. Qarakhanid envoys served as diplomats, merchants, and soldiers in the Song Empire and also participated in updating information about the west. They were asked to draw maps of roads and countries located between Central Asia and China, and as a result, the Qarakhanid territory, including its center in the Chu valley in present-day Kyrgyzstan, appeared in the eleventh-century Song map Hua yi tu.

The Qarakhanid commercial diplomacy in the East was interrupted due to the geopolitical changes that occurred in China and Central Asia during the first half of the twelfth century caused by the Jurchen conquest of the Khitan territories and a vast portion of the Northern Song. The Song lost control of its capital Kaifeng and the northern half of the empire. Therefore, the Song court retreated south and established a new capital in present-day Hangzhou. 
Southern Song authors did not mention Khotan in their records. During this period, the Qarakhanids became a part of the Qara Khitai Empire that was established by the dynastic members of the Khitans, who were forced to move to the west during the Jurchen conquest. Therefore, Chinese sources of the twelfth century applied other designations to the Qarakhanids. They were simply viewed as a territory of the Qara Khitai. At the same time, Jin sources applied the term "Uyghur" (Huihe/Huigu) to the entire territory of Central Asia, including the Qarakhanid realm. Therefore, it is not always possible to differentiate the Qarakhanids from the Qara Khitai or the Uyghurs in the twelfth-century Chinese records. 